\title{
Diagnostic value of ferritin for the severity of dengue infection in children
}

\author{
Farzana Ahmed, Nargis Ara Begum, Md. Moshiur Rahman, Md. Salim Shakur and Shabrina Sharmin
}

\begin{tabular}{|c|c|}
\hline \multicolumn{2}{|l|}{ Article Info } \\
\hline $\begin{array}{l}\text { Pediatric Intensive } \\
\text { Hospital Ltd, Dhak }\end{array}$ & $\begin{array}{l}\text { Care Unit, United } \\
\text { Bangladesh }\end{array}$ \\
\hline $\begin{array}{l}\text { For Corresponden } \\
\text { Farzana Ahmed } \\
\text { farzanaahmedpae }\end{array}$ & @gmail.com \\
\hline Received: & 2 September 2019 \\
\hline Accepted: & 27 September 2019 \\
\hline Available Online: & 3 October 2019 \\
\hline
\end{tabular}

ISSN: 2224-7750 (Online) 2074-2908 (Print)

DOI: 10.3329/bsmmuj.v12i3.43329

Keywords: Dengue; Fever

Cite this article:

Ahmed F, Begum NA, Rahman MM, Shakur MS, Sharmin S. Diagnostic value of ferritin for the severity of dengue infection in children. Bangabandhu Sheikh Mujib Med Univ J. 2019; 12: 146149.

\section{Copyright:}

The copyright of this article is retained by the author(s) [Atribution CC-By 4.0]
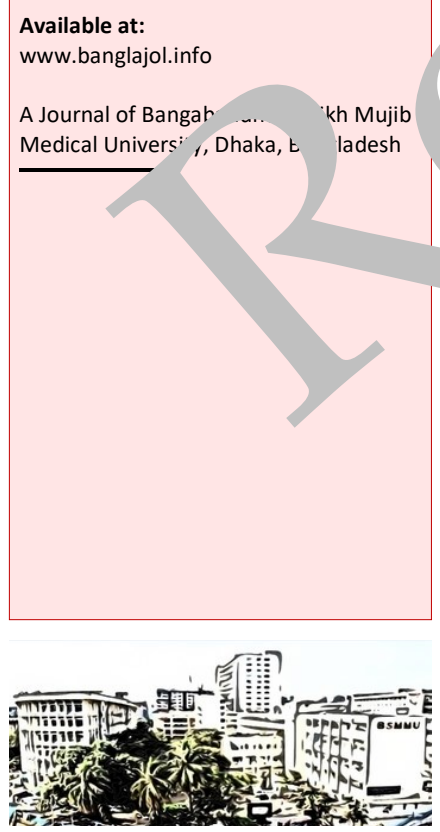

\section{Abstract}

The study was conducted to evaluate whether the severity of dengue fever can be predicted by serum ferritin level or not. This prospective observational study was conducted during the endemic period of dengue fever in 2019. A total of 30 diagnosed ses of dengue fever who presented with bicytopenia during febrile phase of the disease $v_{\text {e }}$ enrolled in this study. Pearson's correlation coefficient was calculated to compare ferritin le, with lowest platelet count and highest hematocrit level and it showed that there was signific relation. There was no difference between the lowest total count of white blood cell ar a seru cerritin level. The severity of dengue fever can be predicted by raised level of serum fer itin.

\section{Introduction}

Dengue fever is a dynamic febrile illness whick can manifest as a mild self-limiting or re life threatening situation following nemorrhage, plasma leakage, or multip organ failure. $1-3$ Now-a-days, it is endemic more than 100 countries in We Pacifl ntin America, Southeast Asia Easte Meditendnean regions and Africa. It is estr. ted that although annually vorldn de $9 f$. nillions human beings re clinical an' estation of deng fever, 39 illions peopre suffer from dengu if tions. $.-i-$

The se el of dengue ever depends on the ; tions wee virus and host's immune respo, e. $\underline{8}$

$\mathrm{N}$ - - -a-day, many hematological parameters ave beer suggested to evaluate the severity of . ase including decreased platelet count, raised hematocrit level, prolonged prothombin ine and activated partial thromboplastin time, liver transaminases, muscular enzymes, cytokines such as IL-6 and IL-10,-15 but there is paucity of researches which can predict bad outcome in dengue fever. Studies conducted by Zhang et al. (2014) $\underline{16}$ at the Caribbean island Aruba; Chaiyaratana et al. (2008) 17 at Thailand concluded that elevated ferritin level in serum is a distinguishing feature of dengue fever. Thanachartwet et al. (2015)프 and Chaloemwong et al. (2018)19 concluded that high hematocrit, thrombocytopenia and leukopenia were associated with severity of the disease. One of the effects of inappropriate activation of tissue macrophages is macrophage activation syndrome and could be responsible for morbidity a $d n$ aity in $d$ ngue fever. Serum ferritin, in acut 'ase $r$ ctant protein, is a surrogate rker of t...ucrophage activa-tion. 20 Elevated le of s rum ferritin during the febrile phase of a e fever might predict the severity of dengue fever during critical phase which r ould help physicians to prepare for the prevention and treatment of extended dengue fever. Thus, it can reduce the morbidity and mortality in dengue fever 20 .

During the endemic period of dengue outbreak in Bangladesh, it was rational to conduct this study to early pickup of lethal cases which was helpful for the prevention of mortality and morbidity.

In this study, we assessed the relationship of serum ferritin concentration with the highest hematocrit, lowest platelet and total white blood cell count.

\section{Materials and Methods}

This study was conducted from June to August, 2019. In total 30 diagnosed cases of dengue fever (Dengue NS 1 positive) who developed bicytopenia during febrile phase of the illness $\underline{7}, \underline{8}$ were included for the study. All participants later developed features of volume overloads in the form bilateral pleural effusions and ascites which resolved at variable period of time. The serum ferritin level was measured from $1 \mathrm{~mL}$ venous blood sample during the $4^{\text {th }}$ or $5^{\text {th }}$ day of onset of febrile phase of the illness (by electrochemiluminescence immunoassayCOBAS e411). 
On a daily basis, disease progression and complete blood count were monitored carefully.

The patients were classified as having non-severe and severe infection as per National guideline of dengue fever. $\underline{21}$

\section{Statistical analysis}

The chi-squared test was done to compare the values of serum ferritin concentration with other parameters of the blood. Additionally Two-tailed, unpaired student's $\mathrm{t}$ test was done to compare the means of different variables Proportions were compared by means of the two-tailed, Fisher's exact test. Correlations between the variables were analyzed by Pearson correlation.

\section{Results}

Figure 1A shows the positive correlation of serum ferritin and high hematocrit value. Pearson correlation value was 0.661 . The result was statically significant $(p=0.000)$.

Figure 1B shows the negative correlation of se am ferritin and lowest platelet count. Pearson co relation value was -0.348 . The result was stat lly significant $(\mathrm{p}=0.05)$.

Figure 1C shows negative corr lation o erum feritin and lowest total cov of whi 2 bloc il count. Pearson correlation value w: -0.172 . the result was not statically ficant $(p=$,

\section{Discussion}

In the presen. cudy, and that higher serum ferriti levf' during febrile phase, significantly associ with lo ver platelet count and higher hematc level uring critical period of dengue fever whic...... mately correlate with the severity of - dicease. Similar findings were noted in other stuun. is well. In South India, Soundravally et al. (2015)2 conducted a research work on 96 febrile $\mathrm{r}$ tients equally divided into dengue and nondengue groups. The plasma ferritin levels were monitored on 4th and 8th day of the onset of fever. Ferritin level was significantly raised in severe dengue fever both in febrile and afebrile phases $(p$ value 0.000 ). In the current study, although we did not compare serum feritin level between the severe and nonsevere dengue fever, we found that higher the level of serum feritin, lower the level of platelet count ( $p$ value 0.000 ). Recently published another study by Petchiappan et al. (2019)르 at Tamilnaru, India also described similar finding on 119 patients with dengue fever. Evalda et al. (2017)느 at Indonesia described the association of high serum

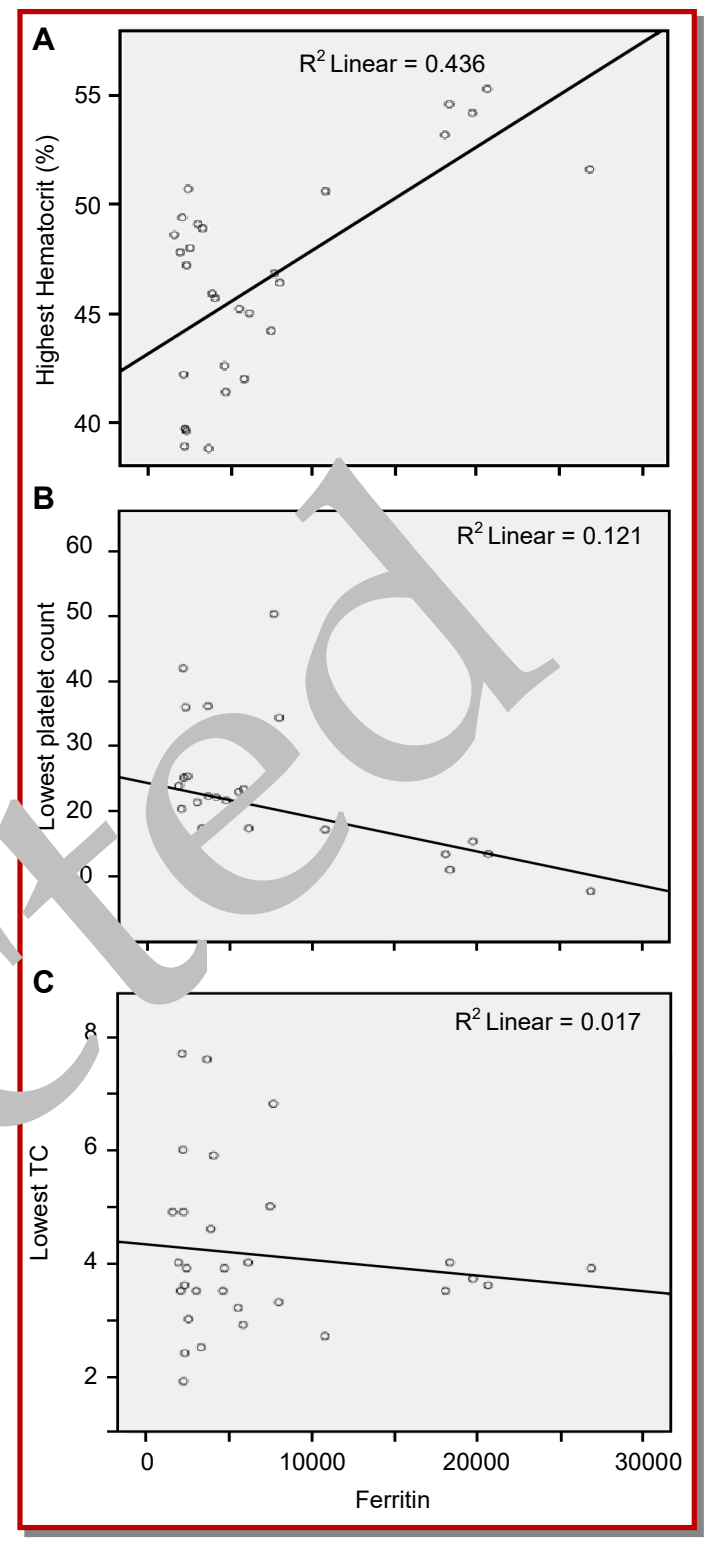

Figure 1: Correlation of serum ferritin level with serum haematocrit level (A), lowest platelet count (B) and lowest total count of white blood cell (C)

ferritin level with dengue shock syndrome in children.

\section{Conclusion}

High serum ferritin level significantly associated with severe dengue fever.

\section{Ethical Issue}

The research protocol was approved by the ethical committee of the United Hospital LTD. Dhaka, Bangladesh. 


\section{Conflict of Interest}

There is no conflict of interest.

\section{Acknowledgement}

Authors would like to thank Mr. Hasan Mahmood Raja, Chairman of United Hospital Limited for his cooperation.

\section{References}

1. Islam QT. Changing epidemiological and clinical pattern of dengue in Bangladesh 2018. J Med. 2019; 20:1-3.

2. Shamsuzzaman AKM. Dengue virus and Aedes mosquitoes: Ecological relationship. J Curr Adv Med Res. 2019; 6: 67-68.

3. Azad MAK, Mohammad H, Alam MB, Saha AK, Ahmed T. Clinical presentation of dengue in 150 admitted cases in Dhaka Medical College Hospital. J Med. 2006; 7: 3-9.

4. Bhatt $\mathrm{S}$, Gething PW, Brady OJ, Messina JP, Farl AW, Moyes CL, Drake JM, Brownstein JS, $\mathrm{J}$ oen AG, Sankoh O, Myers MF, George DB, Jar isch T, Wint GR, Simmons CP, Scott TW, Farrar J, Hay SI. The global distribution an' 'rurder. of dengue. Nature 2013; 496: 504-07.

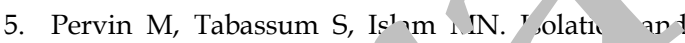
serotyping of dengue ...uses y $\mathrm{m}^{\prime} \mathrm{si}_{\mathrm{x}}$ uito inoculation techniqu ${ }_{\mathrm{r}} \mathrm{m}$ clinic $\mathrm{c}$, pected cases of de rue fever. L rladesh Me....es Counc Bull. 2002; 2 ' 0 ' 1 .

6. Alam $\mathrm{ABMS}$ s at SA, Swa $1 \mathrm{Z}$, Ahmed AU, Karim Paul Zamar S. Clinical profile of der gue to in a. Bangladesh J Child $\mathrm{H}$, llth. $2 \mathrm{O}^{\circ}$; ; 33: 55-58.

7. $\mathrm{Fa}$ a $\mathrm{R}, \mathrm{Av}$ atef $\mathrm{KF}$, Khanum $\mathrm{H}$, Akter $\mathrm{T}$. Prev. engue fever among the patients of different cuonomic status attended at local hospital - nhara. Bangladesh J Zool. 2014; 42: 161-68.

8. Prusty BSK, Momin MAB. Dengue fever with pulmonary alveolar haemorrhage- Common infection with uncommon association: Rare case report. Bangladesh J Med. 2019; 30: 38-40.

9. Ribeiro E, Kassab S, Pistone T, Receveur MC, Fialon P, Malvy D. Primary dengue fever associated with hemophagocytic syndrome: A report of three imported cases, Bordeaux, France. Intern Med. 2014; 53: 899-902.

10. Rajajee S, Ashok I, Manwani N, Rajkumar J, Gowrishankar K, Subbiah E. Profile of hemo-phagocytic lymphohistiocytosis: Efficacy of intravenous immunoglobulin therapy. Indian J Pediatr. 2014; 81: 1337-
41

11. Ray S, Kundu S, Saha M, Chakrabarti P. Hemophagocytic syndrome in classic dengue fever. J Glob Infect Dis. 2011; 3: 399-401.

12. Lehmberg K, Ehl S. Diagnostic evaluation of patients with suspected haemophagocytic lymphohistiocytosis. Br J Haematol. 2013; 160: 275-87.

13. Henter JI, Horne A, Aricó M, Egeler RM, Filipovich $\mathrm{AH}$, Imashuku S, Ladisch S, McClain K, Webb D, Winiarski J, Janka G. Diagnostic and therapeutic guidelines for hemophagocytic lymphohistiocytosis. Pediatr Blood Cancer. 2007; 48: 124-31.

14. Ergonul O, Tuncbıek Baykam N, Celikbas A, Dokuzoguz B. Evalua of serum levels of interleukin (IL)-6, IL-10 imor necrosis factoralpha in patients $v$ th Crii n-Congo hemorrhagic fever. J Infect $T$ is. 2006; 19 . 41-44.

15. Papa A, Binn S, Io E, Ha Xhı A, Kota M, Antoniar's A. tok. hemorr lagic fer _r. J Clin v ..uvl. 2006; 36: 272-76.

Zr ng samer Cl Corticosteroids for dengue fection hrane atabase Syst Rev. 2014; 2014.

17. L varatana W, Chuansumrit A, Atamasirikul K, Tar. rar tchakit K. Serum ferritin levels in child w vith dengue infection. Southeast Asian J Trop Med Public Health. 2008; 39: 832-36.

18 hanachartwet V, Oer-Areemitr N, Chamnanchanunt S, Sahassananda D, Jittmittraphap A, Suwannakudt P, Desakorn V, Wattanathum A. Identification of clinical factors associated with severe dengue among Thai adults: A prospective study. BMC Infect Dis. 2015; 15: 420.

19. Chaloemwong J, Tantiworawit A, Rattanathammethee T, Hantrakool S, Chai-Adisaksopha C, Rattarittamrong E, Norasetthada L. Useful clinical features and haematological parameters for the diagnosis of dengue infection in patients with acute febrile illness: A retrospective study. BMC Hematol. 2018; 18: 20.

20. Petchiappan V, Hussain TM, Thangavelu S. Can serum ferritin levels predict the severity of dengue early?: An observational study. Int J Res Med Sci. 2019; 7: 876-81.

21. National guidelines for clinical management of dengue syndrome. National malaria elimination and aedes transmitted disease control program disease control unit directorate general of health services. $4^{\text {th }}$ ed. 2018.

22. Soundravally R, Agieshkumar B, Daisy M, Sherin J, Cleetus CC. Ferritin levels predict severe dengue. Infection 2015; 43: 13-19.

23. Petchiappan V, Hussain TM, Thangavelu S. Can serum ferritin levels predict the severity of dengue early: An observational study. Int J Res Med Sci. 
2019; 7: 876-81.

24. Evalda P, Soebagyo B, Riza M. Serum ferritin as a predictor of shock in children with dengue infection. Indonesian J Med. 2017; 2: 154-60.

25. Van de Weg CAM, Huits RMHG, Pannuti CS, Brouns RM, van den Berg RWA, van den Ham HJ, Martina BEE, Osterhaus ADME, Netea MG, Meijers JCM, van gorp ECM, Kallas EG. Hyperferritinemia in dengue virus infected patients is associated with immune activation and coagulation disturbances. PLoS Negl Trop Dis. 2014; 8: e3214.

26. Visalakshy SJ, Saminathan SS, Surendran S, Pillai MGK. Hyperferritinemia in dengue fever-correlation between serum ferritin and thrombocytopenia. J Clin Diag Res. 2018; 12: OC07-OC09. 